\title{
Spatial gradient in the distribution of whaler sharks (Carcharhinidae) in Moreton Bay, southeastern Queensland
}

\section{TAYLOR, S.M.}

Western Australian Fisheries and Marine Research Laboratories, PO Box 20, North Beach, WA 6920, Australia. Email: Steve.Taylor@fish.wa.gov.au

JOHNSON, J.W.

Queensland Museum, PO Box 3300, South Brisbane, QLD 4101

BENNETT, M.B.

School of Biomedical Sciences, the University of Queensland, St Lucia, QLD 4072, Australia http://dx.doi.org/10.17082/j.2204-1478.59.2015.2014-08

LSID urn:Isid:zoobank.org:pub:3EB860B0-70CF-4CEA-BD45-A1195AC0CD78

Citation: Taylor, S.M., Johnson, J.W. \& Bennett, M.B. 2015. Spatial gradient in the distribution of whaler sharks (Carcharhinidae) in Moreton Bay, southeastern Queensland. Memoirs of the Queensland Museum - Nature 59: 39-53. Brisbane. ISSN 2204-1478 (Online), ISSN 0079-8835 (Print). Accepted: 15 September 2014. First published online: 31 March 2015.

\begin{abstract}
Experimental gillnetting and setlining provided a detailed account of shark and ray composition at three shallow water sites in Moreton Bay between 2004 and 2007 $(n=350$ elasmobranchs). The species composition of elasmobranchs significantly differed between sites and shark abundance was highest at the western site (St Helena Island, Waterloo Bay). Juvenile Dusky (Carcharhinus obscurus) and Pigeye Sharks (C. amboinensis) were more abundant at the western site and appear to be rare in the eastern bay. Approximately $8 \%$ of the 206 tagged sharks were recaptured, $60 \%$ within two kilometres from their release position, with time at liberty ranging from four to 402 days. The results suggest that the documented east-west gradient in teleost diversity in Moreton Bay also extends to the Carcharhinidae. Further research is recommended to determine whether the diversity patterns observed from the three sites are broadly representative of each of these regions. Setlining and rod and line fishing for sharks in a deeper part of the bay between 1978 and 1992 ( $n=440$ elasmobranchs) revealed a different species composition. The Spottail Shark (C. sorrah) and the Spinner Shark (C. brevipinna) comprised $50 \%$ and $39 \%$ of the catch in this deeper site, respectively, but were rarely caught in shallow regions of the bay, suggesting that the species composition is also partitioned by depth. Western fringes of the bay have been heavily modified by anthropogenic activities and the importance of this area to juvenile whaler sharks needs to be considered. Future sampling at the same fixed locations may provide the opportunity to examine whether recent re-zoning of the Marine Bay Marine Park in 2009, or other factors such as changes in commercial or recreational fishing, have influenced the species composition and abundance of sharks. $\square$ whaler sharks, abundance, nursery area.
\end{abstract}


Sharks play an important role in shaping marine ecosystems in coastal waters (Cortés 1999) and their populations often support commercial and recreational fisheries that provide economic and social benefits to humans (Walker 1998). Many species of sharks use coastal waters as nursery areas which appear to offer new-born (hereon in referred to as neonates) and juvenile sharks protection from larger sharks and an abundance of prey items (Heupel et al. 2007). Proximity to land means that the negative effects of human population growth, such as habitat degradation and loss, pollution, and overfishing can compromise shark populations in some coastal areas (Knip et al. 2010). An understanding of shark abundance and species assemblages in coastal waters is therefore of particular importance.

Moreton Bay is a large, semi-enclosed subtropical bay covering an area of approximately $1600 \mathrm{~km}^{2}$. The bay is bounded by the rapidly expanding Brisbane region of the mainland, to the west, and three sand islands, Moreton, North and South Stradbroke Islands, to the east (Johnson 2010). The environmental conditions vary throughout the bay, with predominantly 'estuarine' conditions (low salinity, high turbidity) in western parts and 'marine conditions' (high salinity, low turbidity) in the eastern bay (Davie \& Hooper 1998). The variety of habitats support a diverse teleost and elasmobranch (sharks and rays) fauna, with over 1,190 fish species reported in the bay and adjacent shelf waters to $200 \mathrm{~m}$ depth (Johnson 2010). Research on elasmobranchs in the bay area has increased significantly over the last decade, which has resulted in the documentation of many aspects of the biology and ecology of numerous species. Topics have included species inventories (Johnson 1999, 2010; Kyne et al. 2005), growth and aging (Huveneers et al. 2013), general shark biology and ecology (Kyne et al. 2011; Dudgeon et al. 2013), sensory biology (Schluessel et al. 2008; Harahush et al. 2009) and parasitology (Cutmore et al. 2010, 2011). In respect to whaler sharks (Carcharhinidae), 14 species have been reported in the bay (Johnson 2010). Although the population structures, diets, habitat occupancy and movement patterns have been described for some species (Taylor \& Bennett 2008, 2013; Werry et al. 2011, 2012), there is little information on spatial relationships among the multiple species within the bay.

Site-specific information on the distribution and abundance of the majority of sharks, and their relationship to the different environmental conditions that occur within the bay are poorly understood for most species. Here, we examined whether the species composition and abundance of whaler sharks differed at three shallow locations (eastern site, central site and western site) in the central region of Moreton Bay, prior to re-zoning of the Moreton Bay Marine Park (MBMP) in 2009. Under this re-zoning plan, there are now nine types of designated areas within the MBMP, four of which relate to recreational and commercial fishing. These are Marine national parks (green zones), Conservation parks (yellow zones), Habitat protection (dark blue zones), and General use areas (light blue zones) (State of Queensland, 2010). We also explored whether the shark fauna differed between shallower and deeper parts of the bay and provide information on the movement and recapture rate of tagged sharks.

\section{MATERIALS AND METHODS}

Gillnetting and setlining 2004-2007. Three fixed sites in central regions of Moreton Bay were chosen for the shallow water sites (Figure 1). The western location was adjacent to St Helena Island, Waterloo Bay $\left(27^{\circ} 24^{\prime} \mathrm{S} 153^{\circ} 12^{\prime} \mathrm{E}\right)$, the central location was Horseshoe Bay, Peel Island $\left(27^{\circ} 30^{\prime} S 153^{\circ} 22^{\prime} \mathrm{E}\right)$ and the eastern location was Deanbilla Bay, North Stradbroke Island $\left(27^{\circ} 31^{\prime} \mathrm{S} 153^{\circ} 24.46^{\prime} \mathrm{E}\right)$. The western site comprised an area with mud/sand substrate and variable seagrass cover dominated by Zostera capricorni. This site is characterised by turbid, estuarine waters in fairly close proximity to the Brisbane River mouth and the Port of Brisbane and has input from sewage and rainfall outflow which drain into the area from the predominantly urban catchment (Dennison \& Abal 1999). The eastern site was a mangrovefringed bay adjacent to oyster leases and the central site was a sandy bay. In comparison 
to the western site, both of these areas are in relatively pristine condition, representing good ecological health and water quality.

A pilot study was conducted between May and October 2004 to examine the feasibility of using gillnets and setlines to capture juvenile sharks for an ongoing postgraduate study on sharks (Taylor 2008). Sampling was conducted at various times of the day and different states of the tide. These fishing methods were successful and subsequent intensive sampling occurred between October 2004 and May 2007. The bottom-set gillnet and bottom-set setline were deployed from a $5 \mathrm{~m}$ research vessel. The gillnet (100 $\mathrm{m}$ long, $2 \mathrm{~m}$ drop and $8.9 \mathrm{~cm}$ mesh size) was anchored at both ends and set in shallow water, typically around $2 \mathrm{~m}$ deep. The set line contained 30 hooks (baited with Sea Mullet Mugil cephalus) equally spaced along a $400 \mathrm{~m}$ length of $4 \mathrm{~mm}$ braided rope which was fished in close proximity to the net (typically 2-5 $\mathrm{m}$ depth). Gangions were $2 \mathrm{~m}$ long and consisted of a shark clip attached to $1 \mathrm{~m}$ of braided nylon cord that connected to $1 \mathrm{~m}$ of multi-strand stainless steel wire and a size $10 / 0$ stainless steel hook. The setline was not used at the central site due to the large number of recreational boats. Nets and lines were typically set one hour before dawn and fished for four hours, although changing weather conditions sometimes resulted in shorter sets. Nets were checked every 30 minutes and all animals were carefully removed from the net and released whenever possible. Hooks were checked every two hours and empty hooks were re-baited with Sea Mullet.

All sharks were measured to the nearest $\mathrm{cm}$ (total length, TL) and those assessed to be in a good condition at the time of capture were tagged in the dorsal musculature at the base of the first dorsal fin. Sharks smaller than $150 \mathrm{~cm}$ TL were brought onboard the boat and tagged with a plastic-tipped dart tag (type PDA, Hallprint, South Australia) while sharks larger than $150 \mathrm{~cm}$ TL were tagged with a stainless steel-tipped dart tag (type SSG, Hallprint, South Australia). Prior to tagging these larger sharks, a rope-noose was looped around the shark's caudal fin and attached to the stern

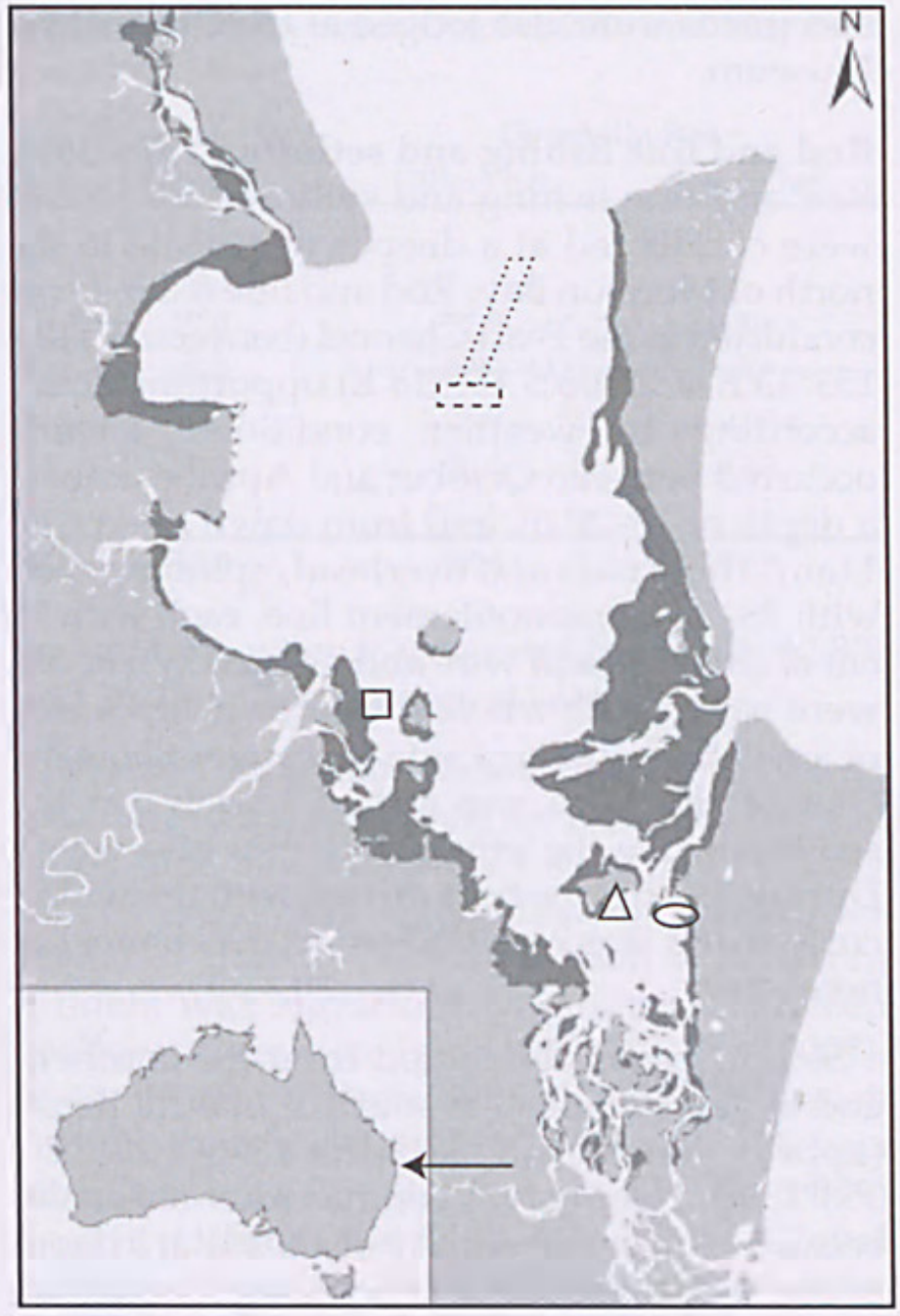

FIG. 1. Map of Moreton Bay indicating the sites where fishing was conducted. Black square $=$ adjacent to St Helena Island, black triangle $=$ Horseshoe Bay, Peel Island, black circle $=$ Deanbilla Bay, North Stradbroke Island. Sampling at these sites was conducted between 2004 and 2007. Black box with small dotted lines $=$ Pearl Channel, black box with large dotted lines $=$ southern end of Pearl Channel to south of Central Banks. Sampling at these sites was conducted between 1978 and 1992. Dark grey shaded areas indicate waters $\leq 3 \mathrm{~m}$ in depth. Offset map and arrow indicates the bay's location on the east coast of Australia.

of the boat. To ensure the safe release of the sharks, whenever possible all handling and tagging time was limited to less than 3 minutes. Although every effort was made to tag and release sharks, some sharks were already dead upon gear retrieval. These sharks were taken back to the University for ongoing dietary and reproductive studies (Taylor 2008). Some 
specimens were also lodged at the Queensland Museum.

Rod and line fishing and setlining 1978-1992. Rod and line fishing and setlining for sharks were conducted at a deeper water site in the north of Moreton Bay. Rod and line fishing was conducted at the Pearl Channel (between $27^{\circ} 12^{\prime} \mathrm{S}$ $\left.153^{\circ} 13^{\prime} \mathrm{E} \& 27^{\circ} 06^{\prime} \mathrm{S} 153^{\circ} 18^{\prime} \mathrm{E}\right)$ opportunistically according to weather conditions. Fishing occurred between October and April, mostly at a depth of $10-20 \mathrm{~m}$, and from dawn to around $11 \mathrm{am}$. Three rods and overhead/spinning reels with $18-27 \mathrm{~kg}$ monofilament line, each with 30 $\mathrm{cm}$ of single strand wire and ganged $5 / 0$ hooks were baited with whole pilchards (Clupeidae), or small Striped Barracuda (Sphyraena obtusata). One of the lines was fished loosely on the sea bed while the others fished in mid-water. During fishing, the boat drifted with the wind/ current and was repositioned to the channel as necessary.

Setlining was conducted from the southern end of Pearl Channel to south of Central Banks (approx. between $27^{\circ} 12^{\prime} \mathrm{S} 153^{\circ} 13^{\prime} \mathrm{E} \& 27^{\circ} 12^{\prime} \mathrm{S}$ $\left.153^{\circ} 15^{\prime} \mathrm{E}\right)$. Fishing was conducted occasionally between November and April, mostly at a depth of $10-20 \mathrm{~m}$, from dawn to 9 or $10 \mathrm{am}$. The setline consisted of a $150 \mathrm{~m}$ section of mainline $(6 \mathrm{~mm}$ braided rope) with 25 litre plastic drum floats at each end, placed parallel with the current and anchored at both ends. Twenty-four droppers were evenly spaced approximately $6 \mathrm{~m}$ apart and consisted of $0.75 \mathrm{~m}$ of $3 \mathrm{~mm}$ braided cord connected to a shark clip and $1 \mathrm{~m}$ of braided stainless steel wire. Each dropper had 2 ganged $9 / 0$ hooks that were baited alternatively with half or whole Striped Barracuda, Sea Mullet, or large squid. Baits were generally suspended off the sea bed.

During all field work, separation of the closely related Common Blacktip Shark (C. limbatus) and the Australian Blacktip Shark (C. tilstoni) in the field was impractical, as the most useful diagnostic feature (counts of precaudal vertebrae) generally could not be taken. However, several specimens that were retained and dissected had precaudal vertebrae counts consistent with the Common Blacktip Shark (94-
98). Vertebral counts taken from another study $(\mathrm{n}=88$ sharks) revealed that $100 \%$ of neonates from Moreton Bay were Common Blacktip Sharks, although one juvenile Australian Blacktip specimen was recorded (Harry et al. 2012). Our material is provisionally listed as the Common Blacktip Shark. Further research is recommended to determine whether the Australian Blacktip is resident in the area, and if so, its community interrelationships with the Common Blacktip Shark. A single ray, tentatively identified as a manta ray was caught and subsequently released from the gillnet. This animal was not identified to species level because it was caught before dawn and a concerted effort was made to release it as soon as possible. Both the Giant Manta Ray (Manta birostris) and, more commonly, the Reef Manta Ray (Manta alfredi) have been reported in southeastern Queensland and as such this individual is tentatively listed as Manta sp. It is possible, however, that this animal may have been a Japanese Devil Ray (Mobula japanica) which has been reported within the MBMP.

\section{STATISTICAL ANALYSIS}

Statistical analysis was restricted to the gillnet data. Catch data were collated as the number of elasmobranchs for each species caught during each fishing event. For those few occasions when an event was greater than or less than four hours, the catch was standardised to a four hour event. Multivariate analyses to identify spatial patterns in the species assemblage was conducted using PRIMER 6.0 (Clarke \& Gorley 2006). Before analysis, data were square root transformed and similarity matrices were constructed using the Bray-Curtis similarity coefficient (Clarke \& Warwick 2001). Ordination of the numerical abundance data from each fishing session was carried out using non-metric multidimensional scaling (MDS). A one-way analysis of similarities (ANOSIM) was used to examine changes in the elasmobranch composition between sites. Similarity percentages (SIMPER) were used to determine which elasmobranchs characterised the assemblage at each site. 
Whaler sharks in Moreton Bay

TABLE 1. Fishing effort by gear type in central regions of Moreton Bay between October 2004 and May 2007

\begin{tabular}{lccccc} 
& \multicolumn{2}{c}{ St Helena } & Horseshoe Bay & \multicolumn{2}{c}{ Deanbilla Bay } \\
Season & Gillnet hrs & Setline hrs & Gillnet hrs & Gillnet hrs & Setline hrs \\
\hline & & & & & \\
Spring (Sep-Nov) & 20.0 & 29.7 & 12.0 & 17.0 & 15.8 \\
Summer (Dec-Feb) & 24.6 & 42.3 & 15.0 & 20.9 & 18.8 \\
Autumn (Mar-May) & 20.8 & 39.2 & 12.0 & 28.9 & 22.5 \\
Winter (Jun-Aug) & 13.8 & 14.1 & 20.0 & 20.0 & 15.8 \\
& & & & & $\mathbf{7 2 . 9}$
\end{tabular}

\section{RESULTS}

Sampling effort 2004-2007. In total, 423 hours of gillnet and setline fishing was conducted at the three central sites between October 2004 and May 2007. Effort was fairly evenly spread among seasons and sites although overall fishing effort was slightly higher at St Helena (Table 1). Sampling effort for shark fishing between 1978 and 1992 was not routinely collected.

Catch by location and season. A total of 350 elasmobranchs from 12 families were caught between 2004 and 2007 (Table 2) and 440 elasmobranchs from four families between 1978 and 1992 (Table 4). In terms of abundance and diversity, Carcharhinidae dominated the numerical catch accounting for $68 \%$ of all elasmobranchs caught at the shallow sites and $86 \%$ of all elasmobranchs at the deeper site. Overall, the Australian Sharpnose Shark (Rhizoprionodon taylori), the Grey Carpetshark (Chiloscyllium punctatum) and the Pigeye Shark (Carcharhinus amboinensis) were the most abundant species at the shallow, central sites (Table 2, Figure 2). The Pigeye Shark, Nervous Shark (C. cautus) and Dusky Shark (C. obscurus) were fairly common in setline catches at St Helena, yet none of these species were caught at Deanbilla Bay and Horseshoe Bay. The catch rate of elasmobranchs at the shallow water sites was lowest in winter when only 23 elasmobranchs were caught (Table 3 ). The Australian Sharpnose Shark was the most abundant elasmobranch during spring, summer and autumn when it accounted for $23.9 \%, 32.8 \%$ and $36.2 \%$ of the numerical catch.

The MDS ordination showed that the St Helena data formed a cluster while the Deanbilla Bay and Horseshoe Bay data points were more widely dispersed (Figure 3). Analysis of similarities revealed that the elasmobranch catch from gillnets was significantly different between shallow water sites (global $r=0.2, P<0.001$ ). A significant difference in the elasmobranch composition occurred between St Helena and Deanbilla Bay (Global $r=0.3, P<0.001$ ) and St Helena and Horseshoe Bay (Global $r=0.1, P<0.04)$. SIMPER revealed that the gillnet catch at St Helena was characterised by the Australian Sharpnose Shark, Eastern Shovelnose Ray (Aptychotrema rostrata) and the Australian Weasel Shark ( $H$. australiensis) which accounted for $16.4(56.7 \%), 5.0(17.1 \%)$ and $4.0(13.9 \%)$ of the average within-group similarity of 28.9. The gillnet catch at Horseshoe Bay was characterised by the Eastern Shovelnose Ray, the Australian Sharpnose Shark and the Common Blacktip which accounted for 2.4 $(34.7 \%), 2.2(31.7 \%)$ and $1.1(16.1 \%)$ of the average within-group similarity of 6.9. The catch data at Deanbilla Bay was characterised by the Scalloped Hammerhead Shark (Sphyrna lewini), the Grey Carpetshark and the Common Blacktip which accounted for $7.6(51.6 \%), 5.1(34.5 \%)$ and 0.7 $(4.7 \%)$ of the average within-group similarity of 14.7 .

The species composition at the deeper site was dominated by the Spottail Shark (C. sorrah) and Spinner Shark (C. brevipinna), both of which 
Taylor, Johnson \& Bennett
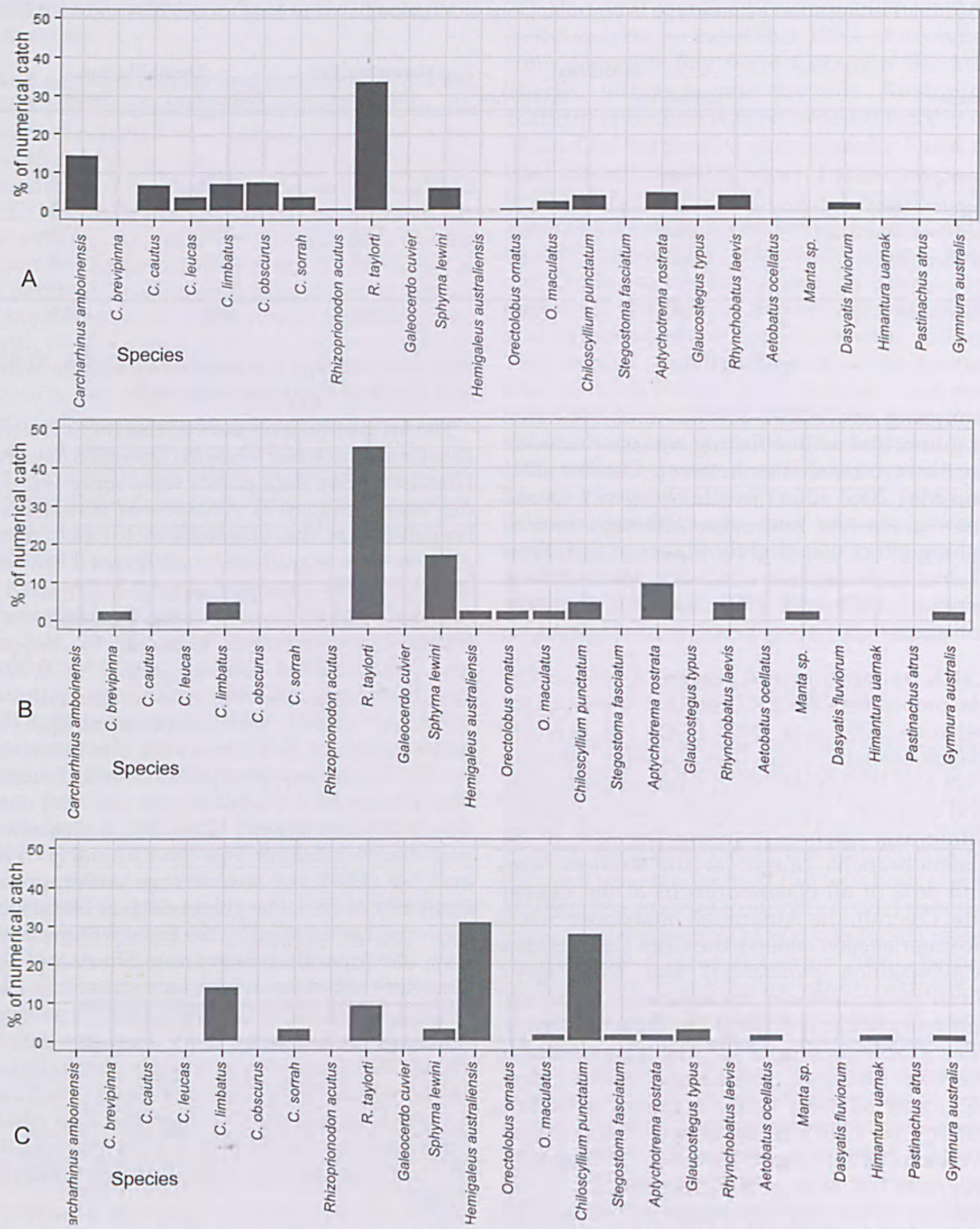

FIG. 2. Numerical catch of elasmobranchs in Moreton Bay at (A) St Helena Island, (B) Horseshoe Bay, Peel Island and (C) Deanbilla Bay, North Stradbroke Island. Sampling at these sites was conducted between 2004 and 2007 ( $n=350$ elasmobranchs). 


\section{Whaler sharks in Moreton Bay}

TABLE 2. The number of elasmobranchs caught by gillnet and setline at shallow, central sites in Moreton Bay, between October 2004 and May 2007.

\begin{tabular}{|c|c|c|c|c|c|}
\hline \multirow[b]{2}{*}{ Species } & \multicolumn{2}{|c|}{ St Helena } & \multirow{2}{*}{$\begin{array}{c}\text { Horseshoe } \\
\text { Bay }\end{array}$} & \multicolumn{2}{|c|}{$\begin{array}{c}\text { Deanbilla } \\
\text { Bay }\end{array}$} \\
\hline & Gillnet & Setline & & Gillnet & Setline \\
\hline \multicolumn{6}{|l|}{ Carcharhinidae } \\
\hline Carcharhinus amboinensis & 3 & 31 & 0 & 0 & 0 \\
\hline C. brevipinna & 0 & 0 & 1 & 0 & 0 \\
\hline C. cautus & 0 & 16 & 0 & 0 & 0 \\
\hline C. leucas & 0 & 8 & 0 & 0 & 0 \\
\hline C. limbatus & 11 & 6 & 2 & 9 & 0 \\
\hline C. obscurus & 7 & 11 & 0 & 0 & 0 \\
\hline C. sorrah & 1 & 7 & 0 & 0 & 2 \\
\hline Rhizoprionodon acutus & 1 & 0 & 0 & 0 & 0 \\
\hline R. taylori & 81 & 0 & 19 & 5 & 1 \\
\hline Galeocerdo cuvier & 0 & 1 & 0 & 0 & 0 \\
\hline \multicolumn{6}{|l|}{ Sphyrnidae } \\
\hline Splyyrna lezvini & 0 & 0 & 1 & 19 & 1 \\
\hline \multicolumn{6}{|l|}{ Hemigaleidae } \\
\hline Hemigaleus australiensis & 14 & 0 & 7 & 2 & 0 \\
\hline \multicolumn{6}{|l|}{ Orectolobidae } \\
\hline Orectolobus ornatus & 0 & 1 & 1 & 0 & 0 \\
\hline O. maculatus & 0 & 6 & 1 & 0 & 1 \\
\hline \multicolumn{6}{|l|}{ Hemiscylliidae } \\
\hline Chiloscyllium punctatum & 9 & 0 & 2 & 18 & 0 \\
\hline \multicolumn{6}{|l|}{ Stegastomidae } \\
\hline Stegostoma fasciatum & 0 & 0 & 0 & 0 & 1 \\
\hline \multicolumn{6}{|l|}{ Rhinobatidae } \\
\hline Aptychotrema rostrata & 11 & 0 & 4 & 1 & 0 \\
\hline Glaucostegus typus & 0 & 3 & 0 & 0 & 2 \\
\hline \multicolumn{6}{|l|}{ Rhynchobatidae } \\
\hline Rhynchobatus laevis & 1 & 8 & 2 & 0 & 0 \\
\hline \multicolumn{6}{|l|}{ Myliobatidae } \\
\hline Aetobatus ocellatus & 0 & 0 & 0 & 1 & 0 \\
\hline \multicolumn{6}{|l|}{ Mobulidae } \\
\hline Manta sp. & 0 & 0 & 1 & 0 & 0 \\
\hline \multicolumn{6}{|l|}{ Dasyatidae } \\
\hline Dasyatis fluviorum & 0 & 5 & 0 & 0 & 0 \\
\hline Himantura uarnak & 0 & 0 & 0 & 0 & 1 \\
\hline Pastinachus atrus & 0 & 1 & 0 & 0 & 0 \\
\hline \multicolumn{6}{|l|}{ Gymnuridae } \\
\hline Gymnura australis & 0 & 0 & 1 & 0 & 1 \\
\hline Total numbers & 139 & 104 & 42 & 55 & 10 \\
\hline
\end{tabular}


TABLE 3 The seasonal catch of elasmobranchs at shallow, central sites in Moreton Bay between October 2004 and May 2007 using a gillnet and setline. Spring = September-November, summer = December-February, autumn $=$ March-May, winter $=$ June-August.

\begin{tabular}{|c|c|c|c|c|}
\hline \multirow{2}{*}{ Species } & \multicolumn{4}{|l|}{ Season } \\
\hline & Spring & Summer & Autumn & Winter \\
\hline \multicolumn{5}{|l|}{ Carcharhinidae } \\
\hline Carcharhinus amboinensis & 19 & 5 & 10 & 0 \\
\hline C. brevipinna & 0 & 1 & 0 & 0 \\
\hline C. cautus & 3 & 4 & 9 & 0 \\
\hline C. leucas & 1 & 7 & 0 & 0 \\
\hline C. limbatus & 8 & 12 & 7 & 1 \\
\hline C. obscurus & 2 & 0 & 11 & 5 \\
\hline C. sorrah & 5 & 5 & 0 & 0 \\
\hline Rhizoprionodon acutus & 1 & 0 & 0 & 0 \\
\hline R. taylori & 22 & 39 & 42 & 3 \\
\hline Galeocerdo cuvier & 0 & 1 & 0 & 0 \\
\hline \multicolumn{5}{|l|}{ Sphyrnidae } \\
\hline Sphyrna lewini & 1 & 10 & 10 & 0 \\
\hline \multicolumn{5}{|l|}{ Hemigaleidae } \\
\hline Hemigaleus australiensis & 9 & 11 & 3 & 0 \\
\hline \multicolumn{5}{|l|}{ Orectolobidae } \\
\hline Orectolobus ornatus & 1 & 0 & 0 & 1 \\
\hline O. maculatus & 0 & 0 & 2 & 6 \\
\hline \multicolumn{5}{|l|}{ Hemiscylliidae } \\
\hline Chiloscyllium punctatum & 9 & 6 & 9 & 5 \\
\hline \multicolumn{5}{|l|}{ Stegastomidae } \\
\hline Stegostoma fasciatum & 0 & 1 & 0 & 0 \\
\hline \multicolumn{5}{|l|}{ Rhinobatidae } \\
\hline Aptychotrema rostrata & 3 & 8 & 4 & 1 \\
\hline Glaucostegus typus & 0 & 0 & 4 & 1 \\
\hline \multicolumn{5}{|l|}{ Rhynchobatidae } \\
\hline Rhynchobatus laevis & 2 & 6 & 3 & 0 \\
\hline \multicolumn{5}{|l|}{ Myliobatidae } \\
\hline Aetobatus ocellatus & 1 & 0 & 0 & 0 \\
\hline \multicolumn{5}{|l|}{ Mobulidae } \\
\hline Manta sp. & 1 & 0 & 0 & 0 \\
\hline \multicolumn{5}{|l|}{ Dasyatidae } \\
\hline Dasyatis fluviorum & 3 & 0 & 2 & 0 \\
\hline Himantura uarnak & 1 & 0 & 0 & 0 \\
\hline Pastinachus atrus & 0 & 1 & 0 & 0 \\
\hline \multicolumn{5}{|l|}{ Gymnuridae } \\
\hline Gymnura australis & 1 & 1 & 0 & 0 \\
\hline Total numbers & 93 & 118 & 116 & 23 \\
\hline
\end{tabular}




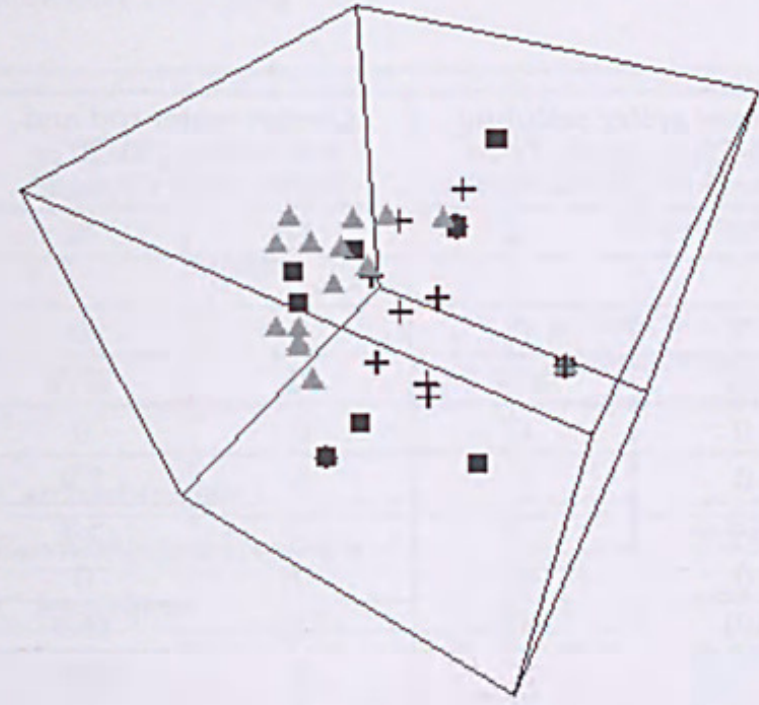

FIG. 3. Multidimensional scaling of the Bray-Curtis similarity matrices derived from the elasmobranch catch in gillnets at three sites in central region of Moreton Bay between 2004 and 2007. Stress value is shown in the top-right corner. Grey triangles $=\mathrm{St}$ Helena, black crosses $=$ Horseshoe Bay, Peel Island, black squares $=$ Deanbilla Bay, North Stradbroke Island.

were rarely caught at the shallower sites (Table 4). The Scalloped Hammerhead Shark also appeared to be fairly common at the deeper site. Most species of carcharhinid and sphyrnid sharks caught at the deeper site were larger than at the shallower sites (Table 5).

Tagging. Between May 2004 and May 2007, 206 carcharhiniform sharks were tagged, most of which were neonates and juveniles. In total, $8 \%$ were recaptured (Table 6 ) with recapture rates highest for the Common Blacktip Shark (19\%), Dusky Shark (11\%) and Spottail Shark (9\%). Of the recaptured sharks, $87 \%$ were caught within $10 \mathrm{~km}$ of their respective release position and $60 \%$ were recaptured within $2 \mathrm{~km}$ from their original capture location. A Pigeye Shark was recaptured in the exact same location over a year later (time at liberty 402 days). Time at liberty ranged from four to 402 days and $44 \%$ of sharks were recaptured within 50 days. Recaptured sharks were caught by recreational fishers $(38 \%)$, in commercial gillnets $(50 \%)$, in crab pots $(6 \%)$ and by the setline used in this study $(6 \%)$.
Shark abundance and species composition. The species assemblages that characterised the three shallow-water sites were markedly different. The Australian Sharpnose Shark dominated the gillnet catch at St Helena and Horseshoe Bay, Peel Island, and was present at Deanbilla Bay, off North Stradbroke Island. This small species of shark reaches a maximum size of approximately $67 \mathrm{~cm}$ TL (Last \& Stevens 2009) and appeared to be particularly susceptible to gillnets, with only a single specimen caught on setlines. Catches of multiple individuals in a single gillnet suggested conspecific association, although it is unknown whether the association is limited to particular cohorts, related to mating activities, or reflects normal foraging behaviour. Variation in both the species present and their relative abundance at the three sample locations highlights localscale $(<25 \mathrm{~km})$ differences in distributions of elasmobranch species within Moreton Bay. While the drivers of the distributions of sharks and rays within the bay are unknown, it is likely that many species are influenced by the 'east-west' gradients in salinity and turbidity that have been documented to influence teleost community structure (Davie \& Hooper 1998). Further sampling at more sites within western, central and eastern fringes of the Bay would help confirm whether the shark abundance and diversity patterns observed from the sites are broadly representative of each of these regions. It must be noted that the selectivity of the fishing gear used in the current study led to the capture of sharks between $39 \mathrm{~cm}$ and $204 \mathrm{~cm}$ TL. Previous research has documented the abundance of several batoids, such as the Bluespotted Maskray (Neotrygon kuhlii), the Brown Whipray (Himantura toshi), and the Common Stingaree (Trygonoptera testacea) (Johnson 2010; Pierce et al. 2011), which were largely absent from this study due to their small size and the selectivity of the fishing gear used. Furthermore, during the experimental fishing in deeper regions of the bay $(10-20 \mathrm{~m}$ in depth), baits were generally fished off the sea-bed, selecting against benthic dwelling elasmobranchs. However, the sampling approach outlined in this 
TABLE 4. The number and percent contribution of elasmobranchs caught by setline and rod and line fishing in shallow and deeper regions of Moreton Bay. Sampling conducted at shallow water sites between 2004 and 2007 and at deeper sites between 1978 and 1992.

\begin{tabular}{|c|c|c|c|c|c|c|}
\hline \multirow[t]{2}{*}{ Species } & \multicolumn{2}{|c|}{$\begin{array}{l}\text { Shallow water setlining } \\
\text { ( }<5 \mathrm{~m} \text { depth, St Helena } \\
\text { and Deanbilla Bay) }\end{array}$} & \multicolumn{2}{|c|}{$\begin{array}{l}\text { Deeper water setlining } \\
(10-20 \mathrm{~m} \text { depth, Pearl } \\
\text { Channel to Central Banks) }\end{array}$} & \multicolumn{2}{|c|}{$\begin{array}{l}\text { Deeper water rod and } \\
\text { line fishing }(10-20 \mathrm{~m} \\
\text { depth, Pearl Channel }\end{array}$} \\
\hline & $\mathrm{N}$ & $\%$ & $\mathrm{~N}$ & $\%$ & $\mathrm{~N}$ & $\%$ \\
\hline \multicolumn{7}{|l|}{ Carcharhinidae } \\
\hline Carcharhinus amboinensis & 31 & 27.2 & 0 & 0 & 0 & 0 \\
\hline C. brevipinna & 0 & 0.0 & 59 & 32.4 & 71 & 27.5 \\
\hline C. cautus & 16 & 14.0 & 0 & 0 & 0 & 0 \\
\hline C. leucas & 8 & 7.0 & 0 & 0 & 5 & 1.9 \\
\hline C. limbatus & 6 & 5.3 & 14 & 7.7 & 15 & 5.8 \\
\hline C. obscurus & 11 & 9.6 & 0 & 0 & 0 & 0 \\
\hline C. sorrah & 9 & 7.9 & 101 & 55.5 & 121 & 46.9 \\
\hline Rhizoprionodon acutus & 0 & 0.0 & 0 & 0 & 9 & 3.5 \\
\hline R. taylori & 1 & 0.9 & 0 & 0 & 0 & 0 \\
\hline Galeocerdo cuvier & 1 & 0.9 & 0 & 0 & 0 & 0 \\
\hline \multicolumn{7}{|l|}{ Sphyrnidae } \\
\hline Sphyrna lewini & 1 & 0.9 & 8 & 4.4 & 34 & 13.2 \\
\hline \multicolumn{7}{|l|}{ Orectolobidae } \\
\hline Orectolobus ornatus & 1 & 0.9 & 0 & 0 & 0 & 0 \\
\hline O. maculatus & 7 & 6.1 & 0 & 0 & 0 & 0 \\
\hline \multicolumn{7}{|l|}{ Hemiscylliidae } \\
\hline Chiloscyllium punctatum & 0 & 0 & 0 & 0 & 1 & 0.4 \\
\hline \multicolumn{7}{|l|}{ Stegastomidae } \\
\hline Stegostoma fasciatum & 1 & 0.9 & 0 & 0 & 0 & 0 \\
\hline \multicolumn{7}{|l|}{ Rhinobatidae } \\
\hline Glaucostegus typus & 5 & 4.4 & 0 & 0 & 0 & 0 \\
\hline \multicolumn{7}{|l|}{ Rhynchobatidae } \\
\hline Rhynchobatus laevis & 8 & 7.0 & 0 & 0 & 0 & 0 \\
\hline \multicolumn{7}{|l|}{ Rhinopteridae } \\
\hline Rhinoptera neglecta & 0 & 0 & 0 & 0 & 2 & 0.8 \\
\hline \multicolumn{7}{|l|}{ Dasyatidae } \\
\hline Dasyatis fluviorum & 5 & 4.4 & 0 & 0 & 0 & 0 \\
\hline Himantura uarnak & 1 & 0.9 & 0 & 0 & 0 & 0 \\
\hline Pastinachus atrus & 1 & 0.9 & 0 & 0 & 0 & 0 \\
\hline \multicolumn{7}{|l|}{ Gymnuridae } \\
\hline Gymnura australis & 1 & 0.9 & 0 & 0 & 0 & 0 \\
\hline Total numbers & 114 & & 182 & & 258 & \\
\hline
\end{tabular}




\section{Whaler sharks in Moreton Bay}

TABLE 5. The size (TL, cm) of Carcharhinidae and Sphyrindae sharks caught in shallow and deeper regions of Moreton Bay. Sampling conducted at shallow water sites between 2004 and 2007 and at deeper sites between 1978 and 1992.

\begin{tabular}{|c|c|c|c|}
\hline \multirow[b]{2}{*}{ Species } & \multicolumn{3}{|c|}{ Size range $(\mathrm{TL}, \mathrm{cm})$} \\
\hline & $\begin{array}{l}\text { Shallow water } \\
\text { (gillnet and setlining, St } \\
\text { Helena, Horseshoe Bay } \\
\text { and Deanbilla Bay) }\end{array}$ & $\begin{array}{l}\text { Deeper water setlining } \\
\text { (10-20 m depth, Pearl } \\
\text { Channel to Central Banks) }\end{array}$ & $\begin{array}{l}\text { Deeper water rod } \\
\text { and line fishing } \\
\text { (10-20 m depth, } \\
\text { Pearl Channel) }\end{array}$ \\
\hline \multicolumn{4}{|l|}{ Carcharhinidae } \\
\hline Carcharhinus amboinensis & $72-164$ & - & - \\
\hline C. brevipinna & 69 & $\sim 100-210$ & $76-230$ \\
\hline C. cautus & $81-149$ & - & - \\
\hline C. leucas & $168-202$ & $\because$ & $150-210$ \\
\hline C. limbatus & $70-114$ & $\sim 100-150$ & $90-166$ \\
\hline C. obscurus & $91-136$ & - & - \\
\hline C. sorrah & $71-123$ & $\sim 90-150$ & $65-150$ \\
\hline Rhizoprionodon acutus & 89 & - & $73-85$ \\
\hline R. taylori & $39-75$ & - & - \\
\hline Galeocerdo cuvier & 204 & - & - \\
\hline \multicolumn{4}{|l|}{ Sphyrnidae } \\
\hline Sphyrna lewini - & $43-84$ & $\sim 100-160$ & $\sim 65-300$ \\
\hline
\end{tabular}

TABLE 6. The number of sharks tagged in Moreton Bay, the number recaptured and the average distance travelled.

\begin{tabular}{|l|c|c|c|c|}
\hline Species & $\begin{array}{c}\text { Number } \\
\text { tagged }\end{array}$ & $\begin{array}{c}\text { Number } \\
\text { recaptured }\end{array}$ & \% recaptured & $\begin{array}{c}\text { Average distance } \\
\text { traveled in km } \\
\text { standard } \\
\text { deviation) }\end{array}$ \\
\hline Carcharhinus amboinensis & 34 & 1 & 2.9 & 0 \\
\hline C. brevipinna & 1 & 0 & 0 & - \\
\hline C. cautus & 6 & 0 & 0 & - \\
\hline C. leucas & 9 & 0 & 0 & - \\
\hline C. limbatus & 26 & 5 & 19.2 & $1.0(1.0)$ \\
\hline C. obscurus & 65 & 7 & 10.8 & $4.9(4.3)$ \\
\hline C. sorral & 11 & 1 & 9.1 & 15 \\
\hline Rhizoprionodon taylori & 31 & 1 & 3.2 & 0 \\
\hline S. lewvini & 13 & 1 & 7.7 & 0 \\
\hline Hemigaleus australiensis & 10 & 0 & 0 & - \\
\hline \multicolumn{5}{|l|}{} \\
\hline Total number & $\mathbf{2 0 6}$ & 16 & 7.8 & \\
\hline
\end{tabular}


study is likely to provide an accurate representation of the whaler shark fauna.

The Spottail Shark and Spinner Shark were particularly abundant at the deeper site, and yet these sharks were rarely caught in the shallow regions. Although experimental fishing at the deeper and shallow sites were conducted during two different time periods, it is unlikely that this time factor was responsible for the different species composition. It is also extremely unlikely that seasonal migrations to and from the shallow and deeper sites were responsible for the different species composition because both sharks were rare in all four seasons at the shallow sites. It has been suggested previously that the Spottail Shark prefers deeper water (Stevens et al. 2000), which may account for its relatively low abundance in shallower nearshore waters of Moreton Bay. This observation and our results suggest that there is some degree of species-separation by depth within Moreton Bay.

The observation that most of the sharks caught in the shallow-water sites were either neonate or juvenile (Taylor \& Bennett 2013), provides support for the existence of nursery areas (sensu Heupel et al. 2007) for several species of Carcharhinidae within the bay. In contrast, most of the sharks caught at the deeper site were relatively large, with many in excess of $200 \mathrm{~cm}$ TL. Why these individuals appear to prefer the deeper areas of the bay is uncertain, although the presence of commercial $\mathrm{crab}$ and prawn fisheries may influence their distributions. Groups of sharks are often seen to follow working trawlers to feed on bycatch that escapes the net, or is discarded during the sorting process. In the years subsequent to when sampling was carried out, there has been a significant reduction in the number of prawn trawling licenses and consequently effort from trawl boats in the area. Hence a regular food resource from escaped and dumped bycatch has been greatly reduced. The implementation of bycatch reduction technology also continues to lessen the amount of discards from existing trawl operators (Courtney et al. 2006). Trawling activity would likely have acted to concentrate sharks in particular areas of the bay and its reduction may have led to significant changes in the abundance, species composition and spatial distribution of sharks within the area.

There may also have been flow-on effects to shark populations from changes in other fisheries in the region. In the $1970 \mathrm{~s}$ and $80 \mathrm{~s}$, seasonally from October to April, vast shoals of Spotted Mackerel (Scomberomorus munroi) were prevalent around the channels and banks of northern Moreton Bay (J. Johnson pers. obs). Our catch data indicated that carcharhinid sharks were most common in the bay during the same months. Pilot studies conducted in this area between May and September resulted in the capture of such low numbers of sharks that sampling during this period was discontinued. From the late 1980s high speed ring-netting techniques started to be employed by commercial fishers in Moreton Bay specifically to target Spotted Mackerel. Escalating commercial catches together with a largely unrestricted recreational take, depleted the mackerel stock to the point that concerns were raised about the sustainability of the fishery (Begg et al. 2005). From December 2002 to April 2003 a ban on targeted netting of Spotted Mackerel and a reduced commercial quota was phased in by the Queensland Government, along with lower recreational bag limits and increased minimum size regulations. Despite these measures, anecdotal evidence suggests size and structure of the Spotted Mackerel population entering south-east Queensland waters have still not nearly recovered to levels approaching that prior to the period when ring-netting was practiced. Recreational catches of 30 or more large Spotted Mackerel per fishing session per boat were regularly achievable by competent anglers in Moreton Bay throughout the 1970s and 1980s. Notwithstanding current bag limits, that has generally been impossible in this area for many years. A reduction in this important food resource has probably had a significant influence on the historical abundance and composition of shark populations in the area. Recent stock status reports (e.g. State of Queensland, 2013) indicate that the Spotted Mackerel population on the east coast is sustainably fished and 
predominantly comprises young fish (mainly within the one to four year old age groups).

The overall recapture rate of sharks in this study was fairly high $(8 \%)$ which likely reflects the large amount of recreational and commercial fishing effort that occurs within Moreton Bay, rather than small population sizes. Recreational fishing effort in the Moreton Bay catchment was estimated to be 337,111 fisher days (77, 634 standard error) between October 2010 and September 2011 (Taylor et al. 2012). Although sharks are targeted by a small number of recreational fishers in the bay, the majority of sharks caught by recreational fishers are released alive (Taylor et al. 2012). Furthermore, current regulations prohibit the harvest of sharks $1.5 \mathrm{~m}$ TL or larger and there is an in possession limit of one shark per person (State of Queensland, 2012). The largest source of fishing mortality of whaler sharks in Moreton Bay occurs in the East Coast Inshore Fin Fish Fishery (ECIFFF) (State of Queensland, 2011). A small number of commercial fishers in Moreton Bay have targeted sharks opportunistically using gillnets for over 40 years. In 2011/12 439t of shark quota was taken in the ECIFFF, 423t of which was taken using monofilament gillnets (State of Queensland, 2013). The stock status for many species of sharks in Queensland is uncertain (State of Queensland, 2011) and the lack of long-term species-specific catch data and the high diversity in the catch composition make it difficult to assess whether population sizes have been affected by commercial fishing. The Department of Agriculture, Fisheries and Forestry is currently collecting and assessing critical information for determining the population status of sharks harvested in Queensland (State of Queensland, 2012).

Most tagged sharks were caught in close proximity to their original capture location and all the Dusky Shark and Pigeye Shark recaptures occurred within western fringes of the bay. Anecdotal reports from a commercial shark fisher with over 40 years' experience in Moreton Bay (John Page, pers comm) suggest that juvenile Dusky Sharks and Pigeye Sharks are not caught in the eastern side of the Bay. Furthermore, a 23 hour active track of a neonate
Dusky Shark ( $99 \mathrm{~cm} \mathrm{TL}$ ) caught in Waterloo Bay in March 2006 also revealed localised movements (Taylor 2008). During the day, this shark was restricted to water less than $2 \mathrm{~m}$ in depth while at night the shark ventured into slightly deeper water from $2-5 \mathrm{~m}$ in depth but remaining within the 'estuarine waters' of Waterloo Bay. More data are clearly needed, although the results from experimental fishing, tagging, acoustic tracking and anecdotal reports from a commercial fisher all suggest that neonate and juvenile Dusky Sharks have a restricted range in western fringes of the Bay.

Management implications. The re-zoning of the Moreton Bay Marine Park in 2009 increased the amount of protection from all forms of fishing (green zones) from $0.5 \%$ to $16 \%$ of the total area. The impacts of this increased protection on the shark fauna is currently unknown; however, the results of future sampling using comparable gear could be compared to that outlined in this study to assess whether the species abundance and composition has changed due to levels of protection, or other identified anthropogenic factors. Neonate and juvenile sharks are abundant in western fringes of Moreton Bay and while occupying these shallow waters may have been an effective evolutionary strategy, these areas are increasingly becoming affected as the human population in southeast Queensland continues to rise. Within Moreton Bay, urbanisation, sand dredging, construction of canal estates and the extension of the Brisbane airport and the Port of Brisbane may have reduced the availability of suitable habitat for sharks in Moreton Bay. Future research should investigate the importance of these nearshore habitats to shark populations throughout Queensland's waters. This would help ensure that shark populations continue to play an important role in Queensland's inshore ecosystems.

\section{ACKNOWLEDGEMENTS}

We are extremely grateful for the fishing advice provided by John Page. The primary author would like to thank the many volunteers who assisted in field work, particularly Dr Scott 
Cutmore, Dr Simon Pierce, Joanna Stead, Dr Tracey Scott-Holland, Sebastian Pardo, John Combs, Dr Adrian Gutteridge, Dr Lindsay Marshall and Dr Chris Rohner. We would also like to thank Kevin Townsend from the Moreton Bay Research Station for maintaining the research boat used in the study. The Primary Investigator's research was supported by the William Edwards Trust UK, a University of Queensland (UQ) Confirmation Scholarship and a Queensland Smart State Award. We thank Dr Wayne Sumpton (Department of Agriculture, Fisheries and Forestry) for his assistance throughout the project. We also wish to thank the Moreton Bay Research Station, Sea World Research and Rescue Foundation and the Tangalooma Wild Dolphin Resort for research support. Sampling was conducted under Queensland General Fisheries Permit PRM03951I and 55543. All procedures were approved by the UQ Animal Ethics Committee. We thank Dr John Healy and two anonymous reviewers for their insightful comments.

\section{LITERATURE CITED}

Begg, G.A., O'Neill, M.F., Cadrin, S.X. \& Bergenius, M.A.J. 2005. Stock assessment of the Australian east coast spotted mackerel fishery. CRC Reef Research Centre Technical Report No. 58, CRC Reef Research Centre,Townsville, Australia.

Clarke, K.R. \& Gorley, R.N. 2006. PRIMER v6: User manual/tutorial. PRIMER-E, Plymouth.

Clarke, K.R., \& Warwick, R.N. 2001. Change in marine communities: an approach to statistical analysis and interpretation, 2nd edition. PRIMER-E: Plymouth.

Cortes, E. 1999. Standardized diet compositions and trophic levels of sharks. ICES Journal of Marine Science 56:707-717 (http://dx.doi.org/10.1006/ jmsc.1999.0489).

Courtney, A.J., Tonks, M.L., Campbell, M.J., Roy, D.P., Gaddes, S.W., Kyne, P.M., \& O'Neill, M.F. 2006. Quantifying the effects of bycatch reduction devices in Queensland's (Australia) shallow water eastern king prawn (Penaeus plebejus) trawl fishery. Fisheries Research 80: 136-147 (http:// dx.doi.org/10.1016/j.fishres.2006.05.005).

Cutmore, S.C., Bennett, M.B. \& Cribb, T.H. 2010. A new tetraphyllidean genus and species, Caulopatera pagein. g.,n.sp. (Tetraphyllidea: Phyllobothriidae), from the grey carpetshark Chiloscyllium punctatum Muller and Henle (Orectolobiformes:
Hemiscyllidae). Systematic Parasitology 77:13-21 (http://dx.doi.org/10.1007/s11230-010-9252-0).

Cutmore, S.C., Theiss, S.M., Bennett, M.B. \& Cribb, T.H. 2011. Hemipristicolo gunterae gen. n., sp. n. (Cestoda: Tetraphyllidea: Phyllobothriidae) from the snaggletooth shark, Hemipristis elongata (Carcharihiformes: Hemigaleidae), from Moreton Bay, Australia. Folia Parasitologica 58:187-196 (http://dx.doi.org/10.14411/fp.2011.019).

Department of Agriculture Fisheries and Forestry 2013. Stock status of Queensland's fisheries resources 2012, pp 120.

Davie, P.J.F. \& Hooper, J.N.A. 1998. Patterns of biodiversity in marine invertebrate and fish communities of Moreton Bay. Pp 331-346. In I.R. Tibbets Hall, N.J., Dennison, W.C., (ed) Moreton Bay and catchment. (School of Marine Science, the University of Queensland: Brisbane).

Dennison, W.C., \& Abal, E.G. 1999. Moreton Bay study - a scientific basis for the healthy waterways campaign. Page 245. South East Queensland Regional Water Quality Management Strategy.

Dudgeon, C.L., Lanyon, J.M. \& Semmens, J.M. 2013. Seasonality and site fidelity of the zebra shark, Stegostoma fasciatum, in southeast Queensland, Australia. Animal Behaviour 85:471-481 (http:// dx.doi.org/10.1016/j.anbehav.2012.12.013). Elsevier Ltd.

Harahush, B.K., Hart, N.S., Green, K. \& Collin, S.P. 2009. Retinal neurogenesis and ontogenetic changes in the visual system of the brown banded bamboo shark, Chiloscyllium punctatum (hemiscyllidae, elasmobranchii). Journal of Comparative Neurology 513:83-97 (http://dx.doi.org/10.1002/ cne.21953).

Harry, A.V., Morgan, J.A.T., Ovenden, J.R., Tobin, A.J., Welch, D.J. \& Simpfendorfer, C.A. 2012. Comparison of the reproductive ecology of two sympatric Blacktip Sharks (Carcharhinus limbatus and Carcharhinus tilstoni) off north-eastern Australia with species identification inferred from vertebral counts. Journal of Fish Biology 81:1225-1233 (http://dx.doi.org/10.1111) j.1095-8649.2012.03400.x).

Heupel, M.R., Carlson, J.K. \& Simpfendorfer, C.A. 2007. Shark nursery areas: concepts, definition, characterization and assumptions. Marine Ecology-Progress Series 337:287-297 (http:// dx.doi.org/10.3354/meps337287).

Huveneers, C., Stead, J., Bennett, M.B., Lee, K.A. \& Harcourt, R.G. 2013. Age and growth determination of three sympatric wobbegong sharks: How reliable is growth band periodicity in Orectolobidae? Fisheries Research 147:413425. Elsevier B.V. (http://dx.doi.org/10.1016/j. fishres.2013.03.014). 
Johnson, J.W. 1999. Annotated checklist of the fishes of Moreton Bay, Queensland, Australia. Memoirs of the Queensland Museum 43(2):709-762.

Johnson, J.W. 2010. Fishes of the Moreton Bay Marine Park and adjacent continental shelf waters, Queensland, Australia. Memoirs of Queensland Museum 54(3):299-353.

Knip, D.M., Heupel, M.R. \& Simpfendorfer, C.A. 2010. Sharks in nearshore environments: models, importance, and consequences. Marine Ecology-Progress Series 402:1-11(http://dx.doi. org/10.3354/meps08498).

Kyne, P.M., Compagno, L.J.V, Stead, J. \& Bennett, M.B. 2011. Distribution, habitat and biology of a rare and threatened eastern Australian endemic shark: Colclough's shark, Brachaelurus colcloughi Ogilby, 1908. Marine and Freshwater Research 62:540-547 (http://dx.doi. org/10.1071/MF10160).

Kyne, P.M., Johnson, J.W., Courtney, A.J. \& Bennett, M.B. 2005. New biogeographical information on Queensland chondrichthyans. Memoirs of the Queensland Museum 50:321-327.

Last, P.R. \& Stevens, J.D. 2009. Sharks and Rays of Australia. CSIRO Publishing, pp 656.

Pierce, S.J., Scott-Holland, T.B. \& Bennett, M.B. 2011. Community composition of elasmobranch fishes utilizing intertidal sand flats in Moreton Bay, Queensland, Australia. Pacific Science 65:235247 (http://dx.doi.org/10.2984/65.2.235).

Schluessel, V., Bennett, M.B., Bleckmann, H.H., Blomberg, S. \& Collin, S.P. 2008. Morphometric and ultrastructural comparison of the olfactory system in elasmobranchs: the significance of structure-function relationships based on phylogeny and ecology. Journal of Morphology 269:1365-1386 (http://dx.doi.org/10.1002/ jmor.10661).

Stevens, J.D., West, G.J. \& Mcloughlin, K.J. 2000. Movements, recapture patterns, and factors affecting the return rate of carcharhinid and other sharks tagged off northern Australia. Marine and Freshwater Research 51:127-141 (http://dx.doi. org/10.1071/MF98158).

State of Queensland 2010. Moreton Bay Marine Park user guide. The State of Queensland, Department of State Development, $44 \mathrm{pp}$.

State of Queensland 2011. Annual status report 2010. East Coast Inshore Fin Fish Fishery. Department of Employment, Economic Development and Innovation, $29 \mathrm{pp}$.

State of Queensland 2012. Recreational fishing rules for Queensland, a quick guide 2011-2012. 26 pp

State of Queensland 2013. Stock status of Queensland's fisheries resources. Department of Agriculture, Fisheries and Forestry, $121 \mathrm{pp}$.

Taylor, S. 2008. Population structure and resource partitioning among Carcharhiniform sharks in Moreton Bay, southeast Queensland, Australia. University of Queensland. PhD thesis. (unpub.)

Taylor, S.M. \& Bennett, M.B. 2008. Cephalopod dietary specialization and ontogenetic partitioning of the Australian weasel shark Hemigaleus australiensis White, Last \& Compagno. Journal of Fish Biology 72:917-936 (http://dx.doi. org/10.1111/j.1095-8649.2007.01771.x).

Taylor, S.M. \& Bennett, M.B. 2013. Size, sex and seasonal patterns in the assemblage of Carcharhiniformes in a sub-tropical bay. Journal of Fish Biology 82:228-241 (http://dx.doi.org/10.1111/ jfb.12003).

Taylor, S.M., Webley, J. \& Mcinnes, K. 2013. 2010 Statewide Recreational Fishing Survey. Department of Agriculture, Fisheries and Forestry, $82 \mathrm{pp}$.

Walker, T.I. 1998. Can shark resources be harvested sustainably? A question revisited with a review, of shark fisheries. Marine and Freshwater Research 49:553-572 (http://dx.doi.org/10.1071/ MF98017).

Werry, J.M., Lee, S.Y., Lemckert, C.J. \& Otway, N.M. 2012. Natural or artificial? Habitat use by the bull shark, Carcharhinus leucas. PLoS One 7(11): e49796. http://doi.10.1371/journal. pone.0049796

Werry, J.M., Lee, S.Y., Otway, N.M., Hu, Y. \& Sumpton, Wu 2011. A multi-faceted approach for quantifying the estuarine-nearshore transition in the life cycle of the bull shark, Carcharhinus leucas. Marine and Freshwater Research 62:1421-1431. 


\section{$2 \mathrm{BHL}$ Biodiversity Heritage Library}

Taylor, Stephen M., Johnson, J W, and Bennett, Michael B. 2015. "Spatial gradient in the distribution of whaler sharks (Carcharhinidae) in Moreton Bay, southeastern Queensland." Memoirs of the Queensland Museum 59, 39-53. https://doi.org/10.17082/j.2204-1478.59.2015.2014-08.

View This Item Online: https://www.biodiversitylibrary.org/item/282460

DOI: https://doi.org/10.17082/j.2204-1478.59.2015.2014-08

Permalink: https://www.biodiversitylibrary.org/partpdf/306752

\section{Holding Institution}

Queensland Museum

\section{Sponsored by}

Atlas of Living Australia

\section{Copyright \& Reuse}

Copyright Status: In copyright. Digitized with the permission of the rights holder.

Rights Holder: Queensland Museum

License: http://creativecommons.org/licenses/by-nc-sa/4.0/

Rights: http://biodiversitylibrary.org/permissions

This document was created from content at the Biodiversity Heritage Library, the world's largest open access digital library for biodiversity literature and archives. Visit BHL at https://www.biodiversitylibrary.org. 